\title{
A Study on the Development of International Students Education in Zhejiang Universities Based on the Student Satisfaction
}

\author{
Jianhua Wei
}

\begin{abstract}
In recent years, with a tremendous increase in the number of international students studying at Chinese universities, the education of international students in Zhejiang Province has developed rapidly, and meanwhile, more and more problems have arisen accommodating international education. Thus, it is the right time to explore the existing problems. As a result, an investigation was carried out based on a sample of 463 international students and their satisfaction in Zhejiang universities, and we got the restrictive factors that might hinder the development of international education in Zhejiang Province. The finding ultimately benefits the healthy development of international education, and also opens the new paths for future research in international education. There are many categories of international students, but the study is confined to those students who opt to learn in the universities outside their home country.
\end{abstract}

Index Terms-International student, restrictive factors, satisfaction.

\section{INTRODUCTION}

Economic globalization has become the fundamental trend of development in the world today. Economic globalization requires the internationalization of talent cultivation, and students' transnational learning is the most direct form of internationalization of talent cultivation. Therefore, it has become an important indicator for measuring the internationalization of higher education, and has been receiving more and more attention from all countries.

According to [1], in 2017, a total of 489,200 international students from 204 countries and regions studied in 935 institutions of higher education in China, and the growth rate has remained above $10 \%$ for two consecutive years. In [2], it is reported 34,550 international students were in Zhejiang Province, ranking fourth in all of the provinces.

The education of international students in Zhejiang Province has developed rapidly in recent years, but we clearly understand that the foundation of international students' education in Zhejiang Province is still weak. Compared with Beijing and Shanghai, there is still a big gap. The development of education for international students in Zhejiang Province is facing multiple pressures. Zhejiang universities have entered a critical stage of development where opportunities and challenges coexist. In order to get the restrictive factors that might hinder the development of the international student education in Zhejiang Province and

Manuscript received November 28, 2018; revised March 2, 2019.

Jianhua Wei is with Zhejiang University of Science and Technology, China (e-mail: weijianhua@zust.edu.cn). provide decision-making reference to the institutions and educational authorities, we carried out the investigation.

\section{THEORY OF STUDENT SATISFACTION AND SATISFACTION SURVEY}

Student satisfaction refers to a general psychological feeling and personal opinion of students on school study and life. Understanding the satisfaction of students not only reveals the students' attitudes towards school but also reflects the performance of school-related work. The student satisfaction theory is constructed on the basis of the consumer theory of the market economy. The theory holds that students are consumers of educational products, and that they have the power to invest in not only education but also which institutions. When they consume educational products or services as individuals, they have certain expectations about what they get from consumer behavior. They will be satisfied when expectations are met. Satisfied students have a high probability of academic success and are expected to become ambassadors and donors in the future [3]. Therefore, as a formal "needs evaluation", student satisfaction assessment is an indispensable core part of any comprehensive evaluation of higher education institutions, which helps schools to adjust and optimize strategies. In the USA, the National College Student Satisfaction Survey began in 1994, and research on student satisfaction in China has gradually increased in recent years.

This study conducts an in-depth investigation on the satisfaction of educational products from the perspective of the costumers, the international students in Zhejiang universities. Under the general trend of the "buyer market" of higher education, the survey on the satisfaction of international students is used to obtain the restrictive factors that hinder the development of international students' education, and provide decision-making reference for the education authorities and Zhejiang universities so that education authorities and universities improve and optimize the international educational environment and adjust their development strategies.

\section{THE MATERIAL AND SUMMARY}

This study was carried out using a questionnaire. The 800 questionnaires were distributed in 15 Zhejiang universities in Hangzhou, Ningbo, Wenzhou, Shaoxing, Jinhua, Yiwu, Lin'an and Jiaxing. 320 copies of the questionnaires were for Chinese language learners, 230 copies for English-taught 
degree program students, and 250 questionnaires for Chinese-taught degree program students. Eventually 463 effective questionnaires were collected and, among them, 196 copies were from Chinese language learners, 153 copies were from English-taught degree program students, and 114 copies were from Chinese-taught degree program students. The ratios were $61.25 \%, 66.53 \%$, and $45.6 \%$.

The design of the questionnaire is based on Likert five-point scale. The satisfaction is divided into 5 scales: 1 means "very dissatisfied", 2 means "dissatisfied", 3 means "neutral or unclear", 4 means "satisfied", and 5 means "very satisfied". The mean value represents the overall satisfaction of the student. The higher the mean, the higher the satisfaction. The survey group conducted targeted individual interviews on the options for students with high levels of dissatisfaction. According to the interview and the survey, it was found that the sample truly reflects the actual status of the educational environment for international students in Zhejiang universities.

\section{RESUlt AND ANALYSIS}

\section{A. Teaching}

Teaching is the core of higher education institutions. The quality of teaching is directly related to the quality of talent cultivation. Therefore, the evaluation on the satisfaction of teaching is very important. In the survey, this section has set up four first-level indicators: courses, majors, faculty, and teaching management. The first-level indicators have different second-level indicators. The first-level indicators "majors" are only for degree program students. The specific survey results are as follows:

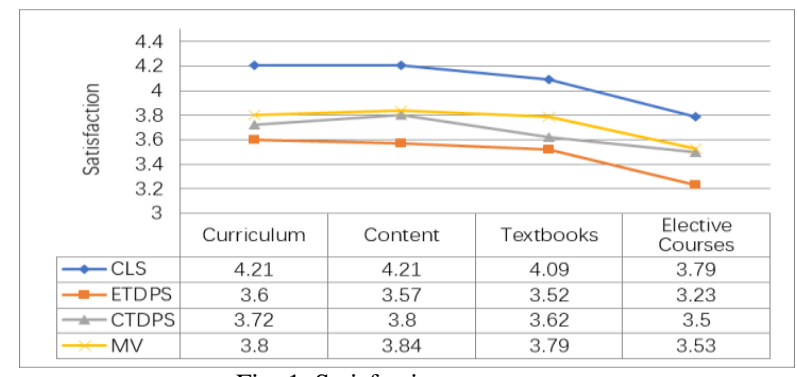

Fig. 1. Satisfaction on courses.

In all the figures and tables, CLS refers to Chinese Language Students, ETDPS refers to English-taught Degree Program Students, CTDPS refers to Chinese-taught Degree Student, and MV refers to the Mean Value.
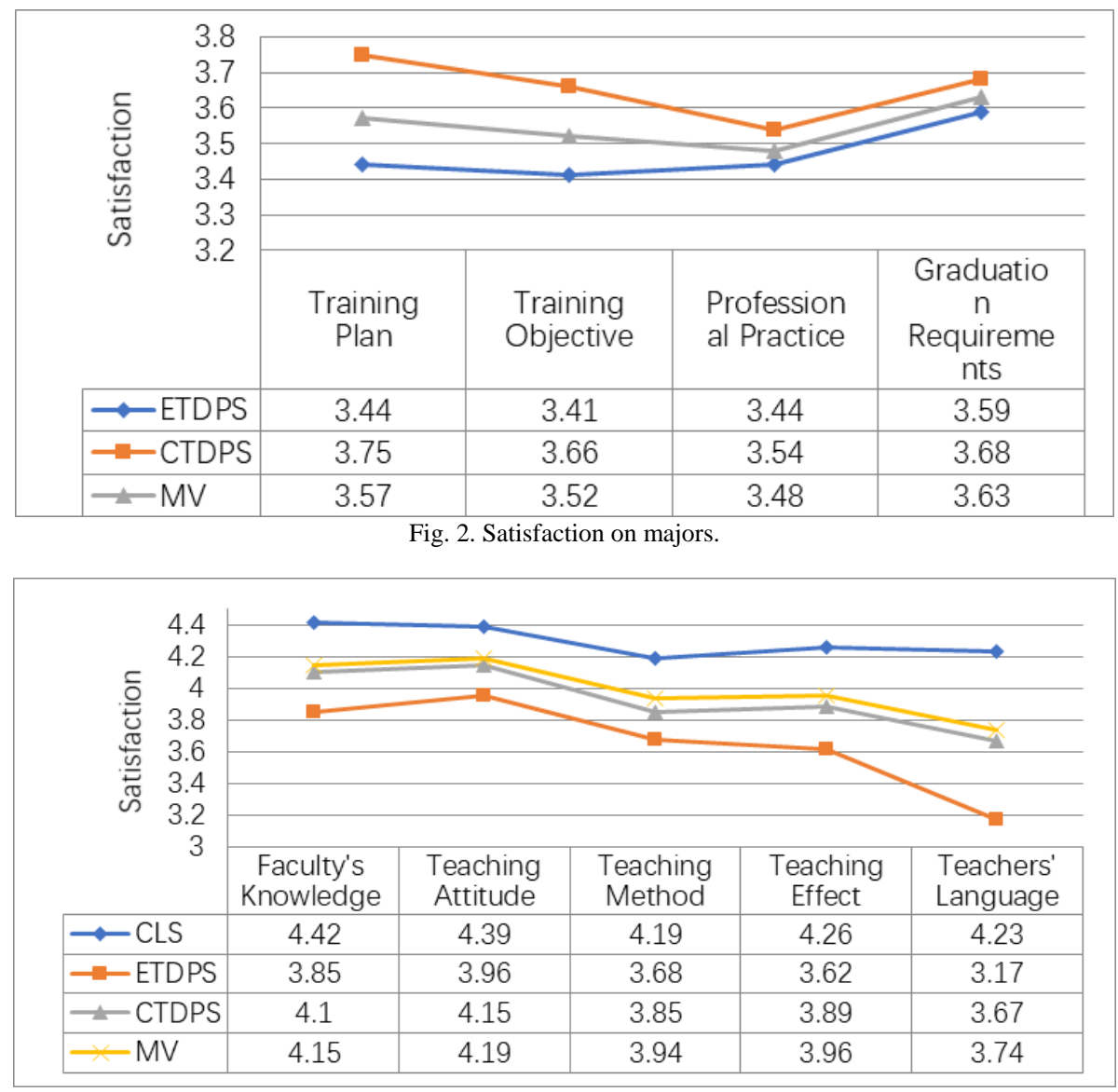

Fig. 3. Satisfaction on faculty.

The data show that the international students have higher overall satisfaction with the teaching of colleges and universities in Zhejiang Province, especially for the teachers' "teaching attitude" and "faculty's knowledge". As a result, the average value has reached 4.19 and 4.15 respectively. The teachers' dedication to teaching has been fully affirmed by international students. However, it is not difficult to find that students of the English-taught degree programs have 
lower satisfaction than the students of Chinese-taught degree programs and Chinese language students, especially in "teachers' language", "elective courses", and "course selection method". The second-level indicators such as "training plan", "training objectives", "professional practice", "management regulation", "registration and exam system", and "make-up exam regulations" are also not ranked as satisfactory. To this end, we conducted targeted interviews on several indicators with low satisfaction.

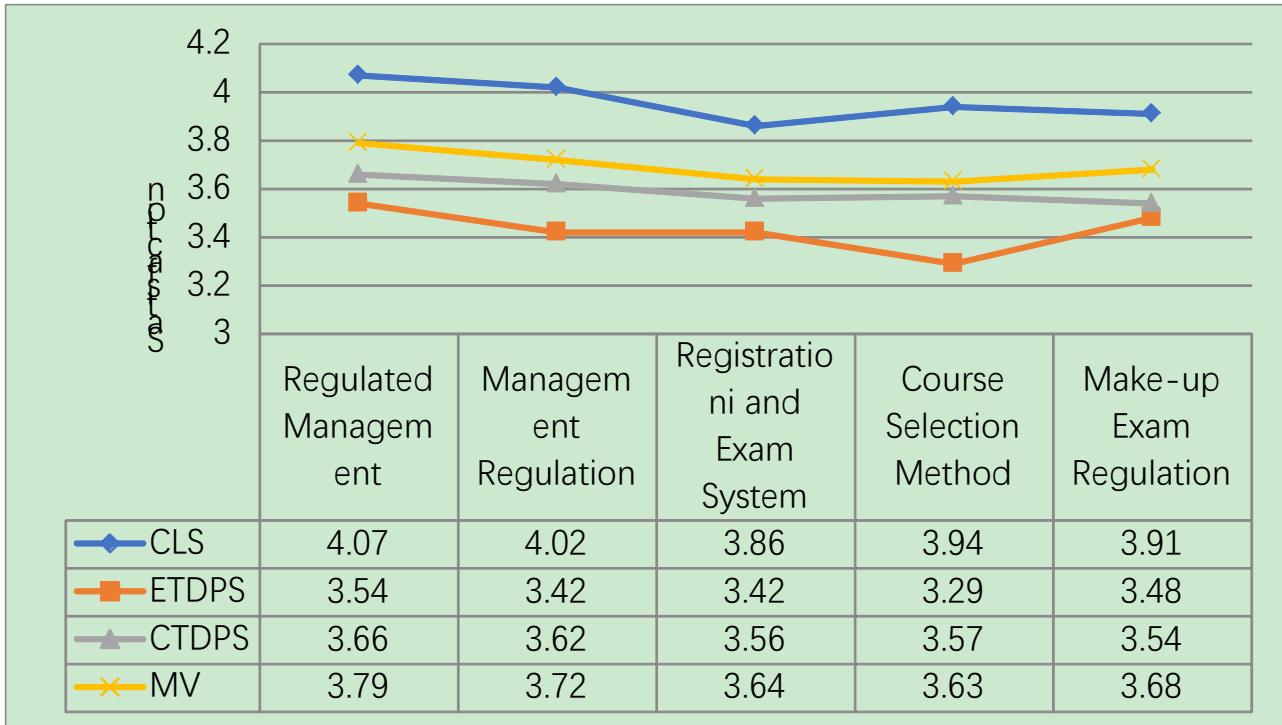

Fig. 4. Satisfaction on teaching management.

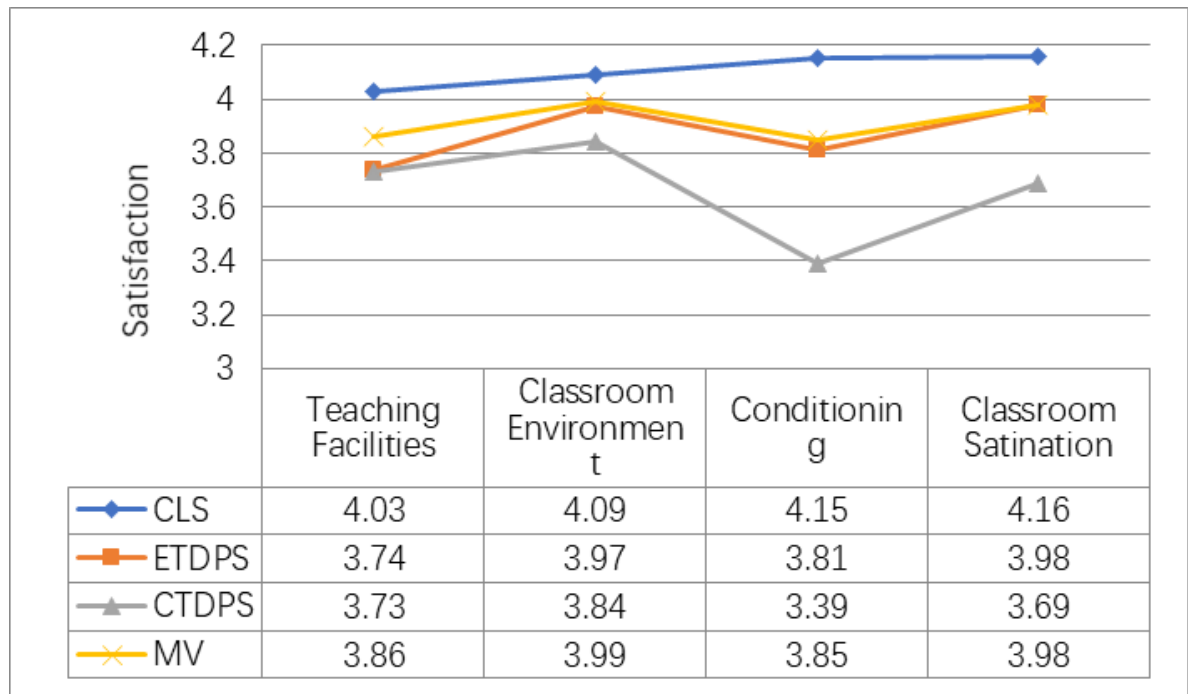

Fig. 5. Satisfaction on teaching facilities.

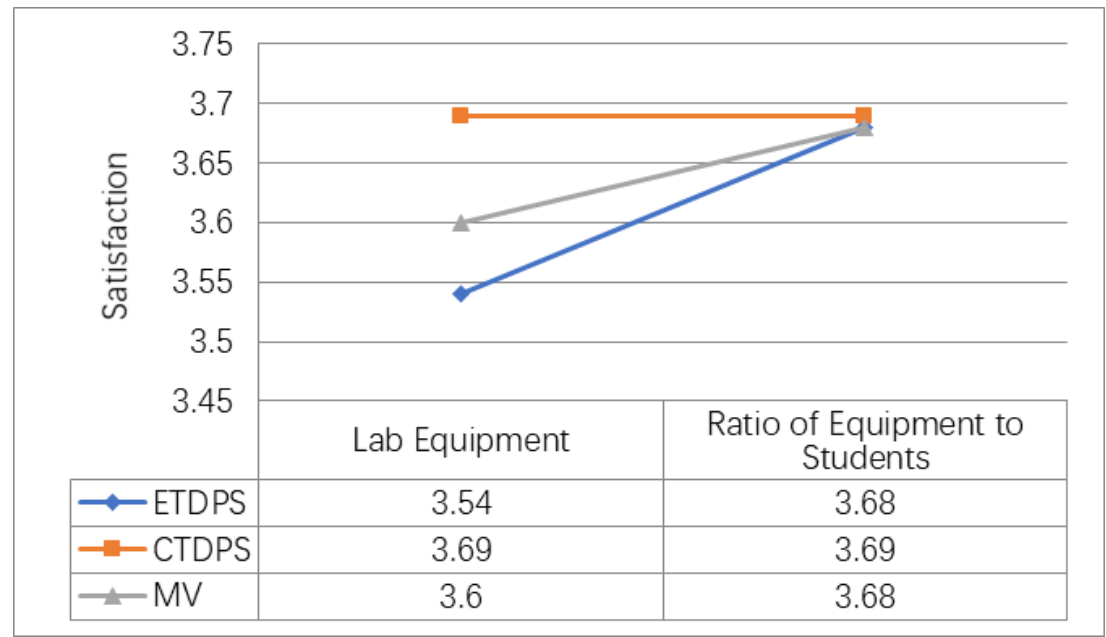

Fig. 6. Satisfaction on laboratories.

Through interviews, it is known that students of English-taught degree programs are not satisfied with the 
English language of some faculty. Some teachers' English is too difficult to understand. Some teachers only read PPT or textbooks. Some teachers are not good enough in English to explain all the questions for students. Many universities have still not paid enough attention to setting up more English-taught professional elective courses because of a shortage of English-speaking faculty. Also, some universities have no English-version registration and exam system. As a result, many students of English-taught degree programs face many difficulties when registering for courses, checking results, and getting other important detailed information. Of course, we also found that many academic students are not familiar with the regulations and do not know what they should do in different periods, and this results in an inconvenience to some academic students. In addition, due to the language requirements, some professional practices are not well developed.

\section{B. School Conditions}

In order to more clearly understand the satisfaction of international students on the school conditions, this study specifically conducts detailed evaluation on the satisfaction about teaching facilities, laboratories, and libraries. "Laboratories" is only for academic students.

TABLE I: SATISFACTION ON LIBRARIES

\begin{tabular}{lcccc}
\hline Indicators & CLS & ETDPS & CTDPS & MV \\
\hline Learning Environment & 3.95 & 3.89 & 4.19 & 3.99 \\
Borrowing Procedures & 3.60 & 3.62 & 3.86 & 3.67 \\
$\begin{array}{l}\text { Open Time } \\
\text { Professional books and }\end{array}$ & 3.60 & 3.47 & 3.52 & 3.54 \\
$\begin{array}{l}\text { audiovisual products } \\
\text { In-house and Website Guide in }\end{array}$ & 3.67 & 3.35 & 3.53 & 3.53 \\
$\begin{array}{l}\text { English } \\
\text { Borrowable Period }\end{array}$ & 3.65 & 3.33 & 3.58 & 3.53 \\
$\begin{array}{l}\text { Borrowable } \\
\text { Quantity }\end{array}$ & 3.70 & 3.60 & 3.73 & 3.67 \\
Librarians' Guidance in English & 3.42 & 3.13 & 3.21 & 3.27 \\
\hline
\end{tabular}

It can be seen from the statistics that the international students are generally satisfied with the school's teaching facilities, laboratories, and libraries, and particularly satisfied with the library's learning environment. The mean value of its satisfaction reached 3.99. However, the satisfaction of the library internationalization is lower, and colleges and universities should pay attention to this fact. The satisfaction on the "librarian's guidance in English" and "in-house and website guide in English" is only 3.13 and 3.33. The learning environment of libraries has been widely recognized by international students, and meanwhile, there is still a long way to come for the libraries to improve the internationalization.

\section{School Website}

In today's information-oriented era, the school website is the "trademark". Establishing a distinctive website is the most direct means of publicity for the school. The interactive nature of the website allows the world to learn more about a school.

The survey found that the international students did not have a high degree of recognition for the website construction of Zhejiang universities, and therefore their satisfaction with the website indicators was relatively low. In the interview, the international students said that the school English websites don't have enough information to meet the needs of the students, since the updates are not timely and the information is outdated. In addition, the international student management department is not good at using the website. The notices of the school are often posted on the window of the notification column, but there is no trace on the website. How to strengthen the construction of the website, so that more international students can better learn about and choose Chinese universities, is an urgent problem for not only Zhejiang universities but also for other universities in China.

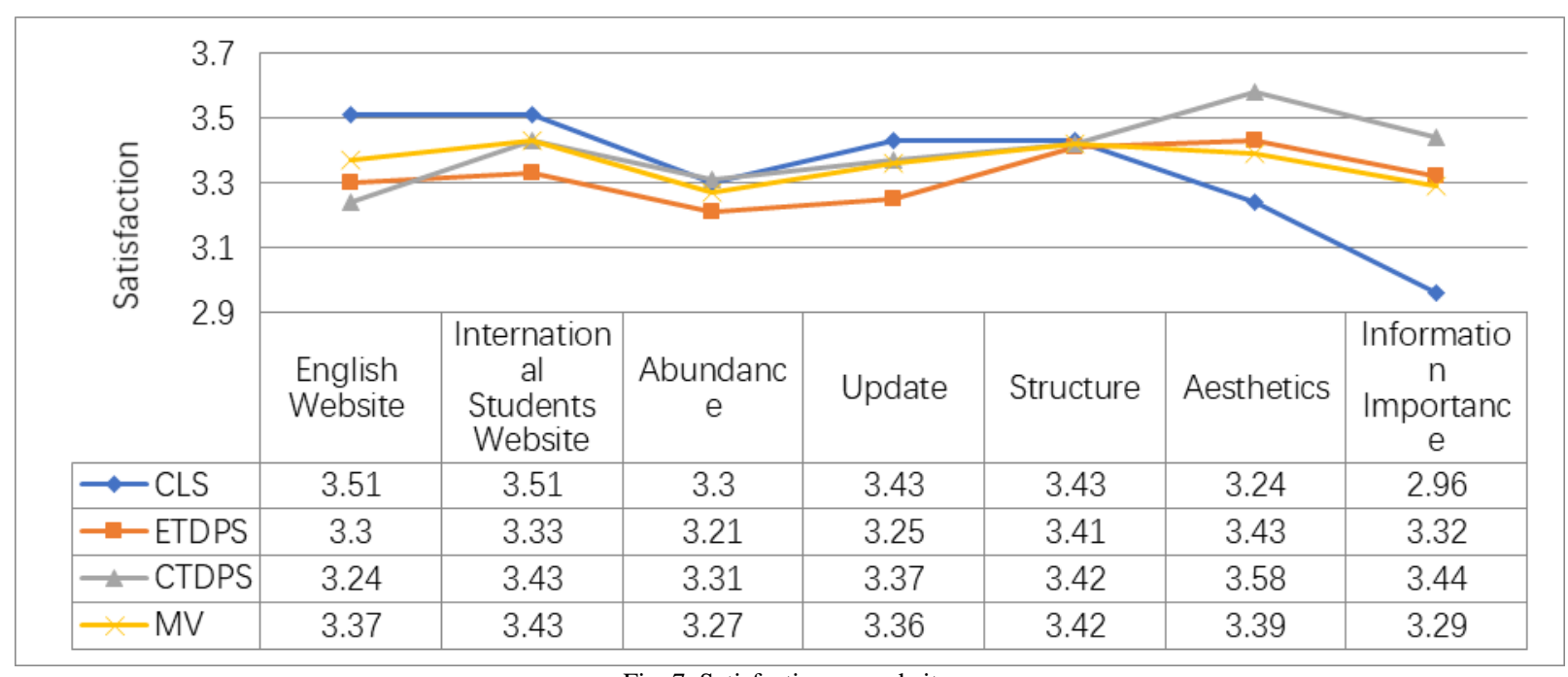

Fig. 7. Satisfaction on website.

\section{Management and Service}

Enthusiastic and efficient administrative management can help international students by making their study lives more comfortable whenever they encounter problems in abroad.

The survey found that Chinese language students have higher overall satisfaction with the management and service, but the overall satisfaction of academic students is relatively low. Many interviewed students mentioned that their academic affairs involve many departments, such as the International Students Office, the Academic Affairs Office, and their own professional colleges, and there is a lack of 
cooperation among the various departments and that simple problems cannot be solved promptly.

\section{E. Sports and Cultural Activities}

As an important part of campus life, cultural activities not only have a subtle influence on college students' ideological concepts, moral sentiments, and spiritual world, but also have important educational functions.

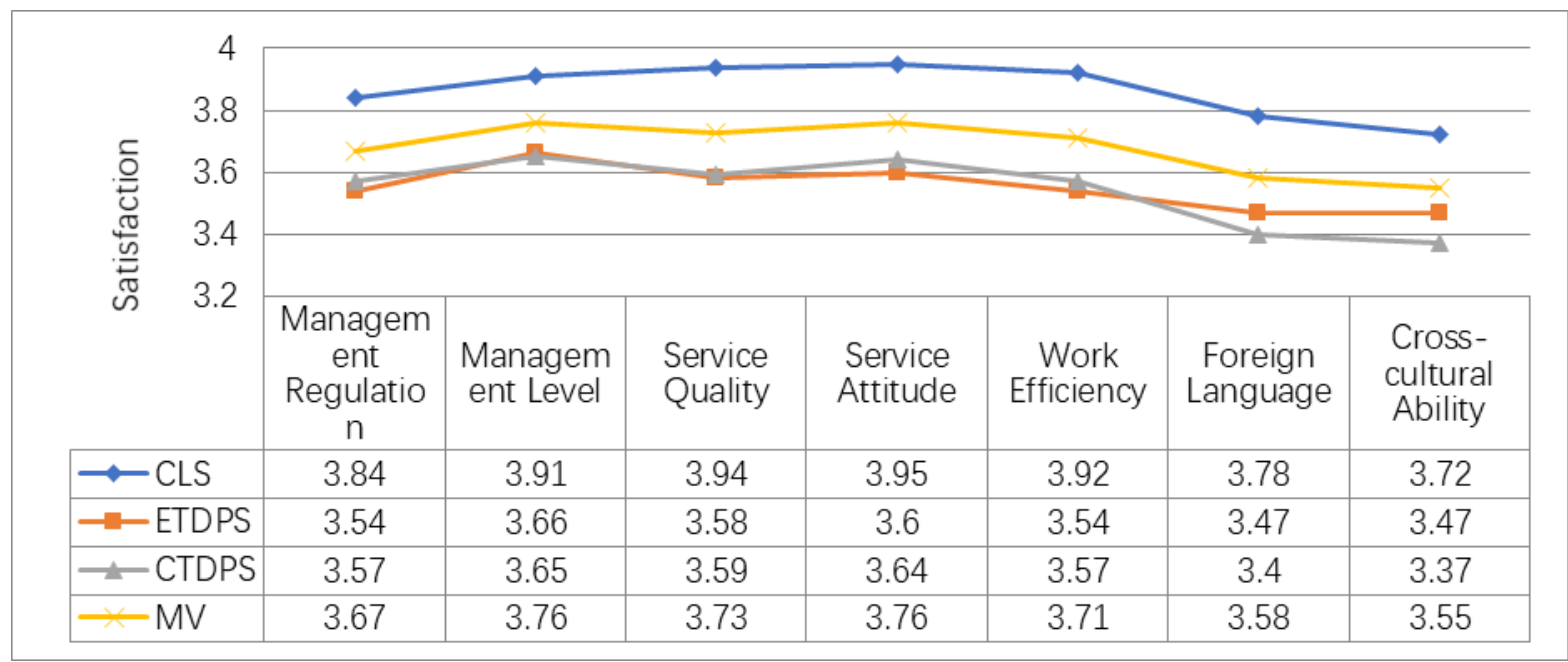

Fig. 8. Satisfaction on management and service.

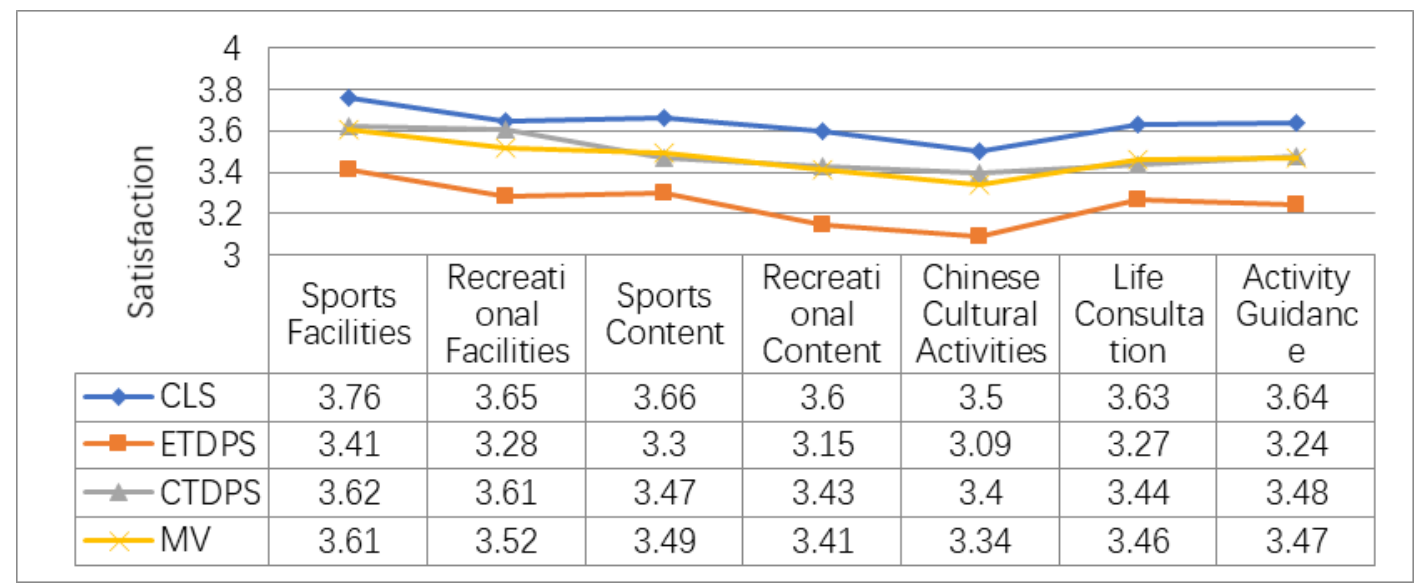

Fig. 9. Satisfaction on sports and cultural activities.

The data showed, English-taught degree program students are dissatisfied with school cultural activities, life consultation, and activity guidance due to language barriers, compared with Chinese language students and Chinese-taught degree program students. These are worthy of great attention from Zhejiang universities. All colleges and universities should carry out cultural activities that are suitable for different students' needs.

\section{F. Logistics Support}

Clothing, food, housing and transportation are the most basic needs of human life. The dietary needs and comfort of school life of the international students ultimately has an impact on the development of their education.

According to the survey data, the living safety in campus is highly recognized by the students, but the work of the TV channels, kitchen facilities, network facilities, and laundry facilities in the dormitory need to be further improved. In terms of diet, international students are less satisfied with the taste of canteen meals. Many students complain that the dining food is limited to just Chinese food and that the TV programs are all Chinese. Some dorms don't even have a public kitchen and so these students complain that the school does not fully consider the actual needs of international students. The development of international student education is a systematic project and logistics support is one of the important links.

\section{TABLE II: SATISFACTION ON ACCOMMODATION}

\begin{tabular}{lcccc}
\hline Indicators & CLS & ETDPS & CTDPS & MV \\
\hline Room Facilities & 3.6 & 3.24 & 3.47 & 3.45 \\
Network Facilities & 3.27 & 2.93 & 3.27 & 3.16 \\
TV Channels & 2.91 & 2.68 & 2.61 & 2.76 \\
Laundry & 3.25 & 3.04 & 3.19 & 3.17 \\
Public Kitchen & 3.16 & 2.79 & 2.99 & 3.00 \\
Living Security & 3.92 & 3.84 & 3.82 & 3.87 \\
Living Charges & 3.55 & 3.51 & 3.46 & 3.51 \\
Sanitation & 3.56 & 3.41 & 3.56 & 3.51 \\
Living environment & 3.75 & 3.64 & 3.66 & 3.69 \\
Shopping & 3.71 & 3.53 & 3.56 & 3.61 \\
Convenience & & & & \\
\hline
\end{tabular}

\section{G. Campus Service}

In order to fully learn about the satisfaction of international students on study and life, this part covers wider service in campus. 
TABLE III: SATISFACTION ON FOOD

\begin{tabular}{lcccc}
\hline \multicolumn{5}{c}{ TABLE III: SATISFACTION ON FOOD } \\
\hline Indicators & CLS & ETDPS & CTDPS & MV \\
\hline Food Taste & 3.42 & 3.06 & 3.29 & 3.27 \\
Food Type & 3.57 & 3.14 & 3.52 & 3.42 \\
Food Cost & 3.77 & 3.53 & 3.62 & 3.65 \\
Sanitation & 3.63 & 3.38 & 3.54 & 3.53 \\
\hline
\end{tabular}

TABLE IV: SATISFACTION ON CAMPUS SERVICE

\begin{tabular}{lcccc}
\hline Indicators & CLS & ETDPS & CTDPS & MV \\
\hline Medical Insurance & 3.57 & 3.14 & 3.34 & 3.37 \\
Chinese Tutoring & 3.27 & 2.92 & 3.14 & 3.12 \\
Mental Health & 3.31 & 3.06 & 3.09 & 3.17 \\
$\begin{array}{l}\text { Service } \\
\text { Campus Hospital }\end{array}$ & 3.49 & 3.08 & 3.00 & 3.23 \\
$\begin{array}{l}\text { Services } \\
\text { Campus Bilingual }\end{array}$ & 3.41 & 2.93 & 3.26 & 3.21 \\
Instruction & & & 3.31 & 3.01 \\
Wireless Network & 3.14 & 2.61 & & \\
\hline
\end{tabular}

The survey found that many international students were not very satisfied with campus services. Through interviews, it was revealed that the dissatisfaction of international students with "medical insurance" mainly stems from the misunderstanding of some students. The international students think that they have purchased medical insurance, and all medical expenses should be paid by insurance companies. Students feel that "insurance is useless" after they aren't reimbursed. This also reminds us that it is necessary to strengthen information communication in the orientation of international students. With the continuous expansion of international students, there are more psychological problems in the international student group. The mental health service of international students' needs to be put on the work schedule.

\section{H. School and Surrounding Environment}

One of the most important factors international students consider is the school's surrounding environment. The convenience of shopping and daily life, for example, is important factors that many international students consider. The data reveal that international students are very satisfied with the campus and surrounding environment of Zhejiang universities. However, due to the lack of large-scale shopping places around Zhejiang colleges and universities, this brings inconvenience to the life of international students and has become one of the unfavorable factors in the development of international students' education.

TABLE V: SATISFACTION ON SCHOOL AND SURROUNDING ENVIRONMENT

\begin{tabular}{lcccc}
\hline Indicators & CLS & ETDPS & CLDPS & MV \\
\hline $\begin{array}{l}\text { Surrounding } \\
\text { Environment }\end{array}$ & 4.07 & 3.82 & 4.00 & 3.97 \\
$\begin{array}{l}\text { Campus } \\
\text { Surrounding }\end{array}$ & 4.20 & 3.94 & 4.20 & 4.11 \\
$\begin{array}{l}\text { Location } \\
\text { Shopping }\end{array}$ & 4.04 & 3.74 & 3.98 & 3.93 \\
$\begin{array}{l}\text { Convenience } \\
\text { Traffic }\end{array}$ & 3.89 & 3.57 & 3.68 & 3.73 \\
\hline
\end{tabular}

\section{City Software Facilities and Environment}

These indicators are set to measure the international students' satisfaction with the living environment of the city. According to the survey, international students generally believe that social security in Zhejiang Province is very good. However, the satisfaction of the public services related to foreign language services, such as "attractions' instruction in foreign language", "information service hot lines", and "foreign language voice services in public transportation" is low. It can be seen that many major cities in Zhejiang Province have to strengthen their public foreign language services.

\begin{tabular}{lcccc}
\multicolumn{5}{c}{ TABLE VI: SATISFACTION ON CITY SOFTWARE AND ENVIRONMENT } \\
\hline \multicolumn{1}{c}{ Indicators } & CLS & ETDPS & CLDPS & MV \\
Public Sanitation & 3.88 & 3.51 & 3.59 & 3.69 \\
$\begin{array}{l}\text { Urban greening and } \\
\text { living environment }\end{array}$ & 3.97 & 3.71 & 3.81 & 3.84 \\
Social Security & 4.07 & 3.73 & 3.90 & 3.92 \\
$\begin{array}{l}\text { Officials and Citizen } \\
\text { Quality }\end{array}$ & 3.81 & 3.57 & 3.69 & 3.70 \\
$\begin{array}{l}\text { Officials Attitude } \\
\text { Attractions' Instruction }\end{array}$ & 3.88 & 3.61 & 3.71 & 3.75 \\
$\begin{array}{l}\text { in Foreign Language } \\
\text { Information Service }\end{array}$ & 3.54 & 3.02 & 3.44 & 3.34 \\
$\begin{array}{l}\text { Hotline } \\
\text { Foreign Language }\end{array}$ & 3.37 & 2.96 & 3.23 & 3.20 \\
$\begin{array}{l}\text { Voice Services in Public } \\
\text { Transportation }\end{array}$ & 3.18 & 2.87 & 3.29 & 3.10 \\
\hline
\end{tabular}

\section{CONCLUSION}

This study serves as a bridge for bringing together international students, institutions and educational authorities. In essence, the responses brought on by students according to their perceptions of learning and their living experiences at the institutions provide the restrictive factors that hinder the development of international student education, and their directions for the improvement of institutions and educational authorities. The results of this study suggest that internationalization of the institutions and cities especially need to improve. Based on the survey, the educational authorities and the institutions are given the following proposals.

The provincial education department, as the educational authority, should make full use of higher education management methods and have external evaluations for teaching, faculty, school conditions, management and services to carry out their supervisory functions in a timely manner. Through timely information feedback and effective guidance, the education authorities might promote institutions to improve the quality of teaching and services, and foster the international brand of Zhejiang higher education. Regarding the lower city internationalization, the education authorities are suggested to actively appeal to all relevant government departments to examine the development of the city from an international perspective and focus on promoting the internationalization of government management, public services, urban facilities, and the concept of citizenship, laying a good environment for studying in Zhejiang, and at the same time achieving a mutually beneficial "win-win" situation.

Raising the leaders' awareness of international education and actively responding to the new challenges brought about by internationalization are vital for the institutions to develop international education. Institutions are suggested to build 
effective communication mechanism and special committee, which might promptly solve the problems among different departments. Increasing the employment of new faculty with overseas study backgrounds and furthering the training of faculty and staff abroad might be the most effective methods for the institutions to improve the satisfaction of international students with teaching focusing on the English level and cross-cultural understanding of some faculty and staff. Additionally, institutions are suggested to strictly implement admission regulation for faculty of English-taught programs, and only those whose English is really good enough should have the qualification to enter English-taught faculty teams. Demonstration courses given by excellent faculty are very necessary and helpful for teacher training and teaching quality. At the same time, enriching the types of elective courses suitable for English-taught students, strengthening teaching management, interpreting the various rules and regulations related to international students in a timely manner, employing qualified staff who are responsible for teaching administration, and putting the internationalization of information resources, staff team construction, and service in the library on the agenda as soon as possible are also necessary for colleges and universities to improve the learning satisfaction of international students.

Studies have shown that international students tend to choose countries with sufficient information, accuracy, timeliness, and clarity [4], and most of the international students search for information through the Internet [5]. This is consistent with the expectations of the students in the survey. In order to make full use of interactive characteristics of the network, institutions are also proposed to utilize the information platform in students' daily management and teaching management. To make full use of Microblog, WeChat and other self-media platforms to interact and serve international students is also what Chinese institutions should actively strive for.

\section{ACKNOWLEDGMENT}

I would like to thank Mr. James Salinas and Ms. Qian Wang for their considerable support and kindness. I am also thankful of all the students who participated in the survey..

\section{REFERENCES}

[1] Ministry of Education of the People's Republic of China. [Online]. Available:

http://www.moe.gov.cn/jyb_xwfb/gzdt_gzdt/s5987/201803/t2018032 9_331772.html

[2] Iedu China. [Online]. Available: http://www.ieduchina.com/news/201712/29804.html

[3] Z. H. Yu, "A review of the American national student satisfaction on study," Comparative Education Review, vol. 193, pp. 60-64, June 2006.

[4] A. Bourke, "A model of the determinants of international trade in higher education," The Service Industries Journal, vol. 20, pp. 110-138, January 2000.

[5] British Council, Education UK, Positioning for Success[R], Manchester: British Council, 2003.

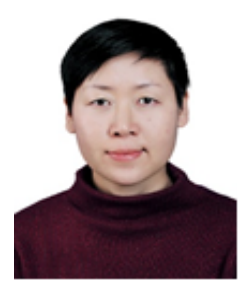

Jianhua Wei received the master degree in linguistics and applied linguistics in foreign languages from Zhejiang University in 2003. Since March 2007, she has been with International Students Affairs Center, Zhejiang University of Science and Technology. 